\title{
THE EFFECT OF METHEMOGLOBIN FORMATION IN SICKLE CELL DISEASE *
}

\author{
By ERNEST BEUTLER with THE technical Assistance of BARBARA J. MIKUS
}

(From the Department of Medicine, City of Hope Medical Center, Duarte, Calif.)

(Submitted for publication January 18, 1961 ; accepted June 15, 1961)

On a biochemical level, sickle cell disease is perhaps the most completely understood disease of man. In spite of this, no satisfactory treatment is available to patients afflicted with this disorder.

The clinical manifestations of sickle cell anemia are varied. Some of the complaints of patients with this disease can be ascribed directly to the lack of oxygen-carrying capacity of the blood. Other symptoms, however, such as the painful crises, the leg ulcers and bone infarcts, are not due to anemia alone. They do not occur in other anemias of equal severity and must thus be ascribed to additional factors. One such factor might be the distortion which sickle cells undergo when the oxygen tension is lowered. Any means by which the shape change of red cells could be inhibited might, therefore, benefit patients with this disorder. Reports of attempts to modify the sickling process by changing the $\mathrm{pH}$ of the environment of red cells through the administration of sodium bicarbonate (1) or by poisoning red cell carbonic anhydrase with acetazolamide (Diamox) have been published (2). Clinical results of acetazolamide treatment have been disappointing (3). We are not aware of published confirmation of the effect of alkali therapy on the clinical course of sickle crises, although a recent study (4) showed that it was not possible to influence in vivo sickling by intravenous administration of bicarbonate. The effect of older therapies on sickle cell disease has recently been reviewed by Dacie (5). None is considered effective. To our knowledge, studies of the effect of any drug therapy on in vivo red cell survival have not been published.

\footnotetext{
* Supported in part by USPHS Grant no. H-5313. A portion of this work was carried out in the Department of Medicine and the Argonne Cancer Research Hospital, operated by the University of Chicago for the U. S. Atomic Energy Commission. Presented in part at the 1960 Annual Meeting of the American Society of $\mathrm{He}$ matology, November 30, 1960, Montreal, Canada (46).
}

A recent review (6) stimulated us to approach this problem from a different point of view. Itano (7) had demonstrated that complete conversion of sickle hemoglobin to the methemoglobin derivative prevented the sickling process. It seemed probable that conversion of only a part of the hemoglobin of sickle cells to methemoglobin would result in partial inhibition of the sickling process. The studies of Greenberg, Kass and Castle (8) have demonstrated that the mean corpuscular sickle hemoglobin concentration (MCSHC) was important in determining whether pronounced clinical symptoms of sickle cell disease were present. Those patients whose $\mathrm{MCSHC}$ values were less than $15 \mathrm{~g}$ per cent were not anemic and had no painful crises. Hemoglobin converted to methemoglobin would be removed from the oxyhemoglobin-reduced hemoglobin equilibrium. In this way the MCSHC of sickle cells would in effect be diminished when methemoglobin was formed. Thus, inhibition of sickling might take place in patients treated with methemoglobinforming agents.

Furthermore, it has been shown that the lowest gelling point of mixtures of $\mathrm{S}$ hemoglobin with other hemoglobins depends not only on the absolute concentration of sickle hemoglobin in the solution, but also on the type of the other hemoglobins (9). In addition, sickling of red blood cells of infants with sickle cell trait has been found to correlate not with the absolute quantity of sickle hemoglobin in the red cells, but rather with the reciprocal of the amount of fetal hemoglobin present (10). Therefore, it appeared at least theoretically possible that methemoglobin might interfere with the sickling process to a greater extent than would be expected from its effect in removing hemoglobin from the $\mathrm{Hb} \rightleftarrows \mathrm{HbO}_{2}$ equilibrium, alone.

Proceeding on the premise that it may be possible to benefit patients with sickle cell anemia by inhibiting the sickling process, even if they are at 
TABLE I

Laboratory data on five patients with sickle cell anemia *

\begin{tabular}{|c|c|c|c|c|c|c|c|c|}
\hline \multirow[b]{2}{*}{ Patient } & \multirow[b]{2}{*}{$\mathrm{Hb}$} & \multirow[b]{2}{*}{ Hct } & \multirow[b]{2}{*}{$\mathbf{R B C}$} & \multirow[b]{2}{*}{ Retic. } & \multirow{2}{*}{$\begin{array}{l}\text { Appearance of } \\
\text { RBC on smear }\end{array}$} & \multirow{2}{*}{$\begin{array}{l}\text { Alkali- } \\
\text { resistant } \\
\text { Hb }\end{array}$} & \multicolumn{2}{|c|}{ Bilirubin } \\
\hline & & & & & & & Direct & Total \\
\hline L.A. & $\begin{array}{r}g \% \\
7.3\end{array}$ & $\begin{array}{c}\% \\
27.5\end{array}$ & $\begin{array}{c}10^{6} / \mathrm{mm}^{3} \\
2.80\end{array}$ & $\begin{array}{c}\% R B C \\
11.5\end{array}$ & $\begin{array}{l}\text { Sickling, } \\
\text { Howell-Jolly } \\
\text { bodies, normo- } \\
\text { blasts, target } \\
\text { cells }\end{array}$ & $\%$ total & \multicolumn{2}{|c|}{$m g \%$} \\
\hline B.W. & 10.0 & 27 & 3.24 & 6.1 & $\begin{array}{l}\text { Sickling, } \\
\text { many target } \\
\text { cells }\end{array}$ & 4.52 & 0.30 & 0.60 \\
\hline T.P. & 7.37 & 23.5 & 2.65 & 14.3 & Sickling & 4.64 & & \\
\hline J.G. & 6.2 & 19 & 1.97 & & Sickling & 3.90 & 2.22 & 3.34 \\
\hline J.R. & 8.0 & 24 & 2.53 & 10.0 & Sickling & 3.44 & 0.80 & 3.80 \\
\hline
\end{tabular}
each.

* All 5 patients had SS hemoglobin shown by paper electrophoresis, and the glutathione stability test was normal in

the same time deprived of a certain quantity of oxygen-carrying capacity, we have undertaken an investigation of the effect of such chemical modification of sickle hemoglobin in patients with sickle cell disease. After these studies had been undertaken and a preliminary communication had been published (11), we learned that in his thesis Itano (7) had suggestéd that clinical investigations of the treatment of sickle cell disease with sodium nitrite might be carried out. At his suggestion, preliminary trials were carried out by Dr. J. C. S. Paterson. In long-term experiments, 300 to $500 \mathrm{mg}$ sodium nitrite in divided daily doses was well tolerated and, although subjective improvement was noted, there was little evidence of hematological improvement. In acute experiments the side effects of sodium nitrite administration by infusion in anemic patients were found to be sufficiently troublesome to necessitate interrupting his studies. These observations have not been published (12).

\section{MATERIALS AND METHODS}

A. Patients. Five Negro women between the ages of 21 and 33 volunteered for these studies. The pertinent admission laboratory data are given in Table I. No blood transfusions were given to any of the patients during the course of the studies.

$B$. Determination of oxygen tension sickling curves. The following gas mixtures were obtained from a commercial source and the exact gas content assayed in each case 1 (except for the 1 per cent $\mathrm{O}_{2}$ mixture) : $0,1,3,5$, 10 and 20 per cent $\mathrm{O}_{2}$. The $\mathrm{CO}_{2}$ content varied from 8.1 to 10.0 per cent. The balance of gas was $\mathrm{N}_{2}$. The actual $\mathrm{O}_{2}$ content has been used in calculating the $\mathrm{pO}_{2}$ throughout, except in the case of 1 per cent $\mathrm{O}_{2}$. Each gas mixture was passed through a gas-washing bottle filled with distilled water.

It was found in preliminary experiments that consistently satisfactory results relating oxygen tension to percentage sickling could not be obtained on washed, resuspended red cells, so that it was necessary to carry out studies on whole blood samples. Accordingly, heparinized blood was obtained from each subject and $1 \mathrm{ml}$ was introduced into a $500 \mathrm{ml}$ separatory funnel (total volume, $650 \mathrm{ml}$ ) which was employed as a tonometer. In studies done on Subject T.P., $2.5 \mathrm{ml}$ was used. The space in the separatory funnel was flushed with the appropriate gas mixture at a rate of $6 \mathrm{~L}$ per minute; it was stoppered and the stopcock closed. The funnel was then rotated at room temperature $\left(22\right.$ to $\left.25^{\circ} \mathrm{C}\right)$ in such a manner as to spread the blood in a thin film on the surface of the glass. After 5 minutes, the gas inside the funnel was again flushed out for 30 seconds at a flow rate of approximately $6 \mathrm{~L}$ per minute and the rotating process repeated. After a third flushing and period of rotation, the funnel was flushed with gas a fourth time for 30 seconds and a drop of blood was introduced under oil from the stem of the funnel into a fixative containing 5.0 per cent formalin, ${ }^{2} 0.010 \mathrm{M} \mathrm{Na}_{2} \mathrm{HPO}_{4}$ and $0.138 \mathrm{M} \mathrm{NaCl}$ which had been saturated with the gas with which the blood sample had been equilibrated. This fixative was designed to give a final $\mathrm{pH}$ of from 6.6 to

${ }^{1}$ Courtesy of Mr. John Barr, chief technician, Cardiac Physiology Laboratory, City of Hope Medical Center.

${ }^{2}$ Solution of formaldehyde, 37 per cent by weight, USP, Merck. 
6.8. After 15 to 30 minutes' fixation, a droplet of blood was introduced into a counting chamber and approximately 200 cells were enumerated; the percentage of distorted cells was recorded. The blood of patients without sickle hemoglobin but with a similar degree of anemia was studied to determine the control level of red cell distortion.

In most studies a red cell which deviated in any appreciable manner from a regular discoid shape was considered to be distorted. In one study more rigid criteria for sickling were employed: cells were considered to be distorted significantly only if the longest diameter of the cell was 2.5 times the shorter diameter, or if there were two distinct points on the cell.

C. Methemoglobin, hemoglobin, alkali-resistant hemoglobin and Heinz bodies. Methemoglobin and hemoglobin determinations were carried out by the method of Evelyn and Malloy (13), modified by the addition of 0.02 per cent saponin to the $0.0167 \mathrm{M}$ buffer, and standardized against a commercially available cyanmethemoglobin standard (Acuglobin, Ortho Pharmaceutical Corp.). In measuring the hemoglobin and methemoglobin content of the fractional hemolysates produced by differential osmotic hemolysis, the method of Evelyn and Malloy was modified in that the determinations were carried out at a $\mathrm{pH}$ of 7.4 instead of 6.6. Appropriate conversion factors derived empirically for this $\mathrm{pH}$ were used.

The method of staining Heinz bodies has been described previously (14). Alkali-resistant hemoglobin was measured by a slight modification of the method of Betke, Marti and Schlicht (15): the erythrocytes were washed only once before lysis. Results were identical with those obtained when the original procedure was employed. Normally, less than 0.8 per cent of the hemoglobin is alkali-resistant when measured by this technique.

D. Drugs. Sodium nitrite was administered in the form of 1 grain tablets (Eli Lilly \& Co.). Para-aminopropriophenone (PAPP) (Eastman Organic Chemical Corp.) was dissolved in propylene glycol at a concentration of $10 \mathrm{mg}$ per $\mathrm{ml}$. PAPP solutions were prepared at least weekly. Both drugs were administered by the oral route. The pharmacology of methemoglobin formation by sodium nitrite and PAPP has been studied in experimental animals and in human subjects and will be reported elsewhere (16). A single oral dose of sodium nitrite tablets or of PAPP dissolved in propylene glycol induces a peak level of methemoglobinemia within approximately 1 hour, with a gradually declining level thereafter. If either of these drugs is administered every 4 hours at the same dosage level, a gradual increase in the blood methemoglobin concentration occurs and the level of methemoglobin is exceedingly stable from hour to hour.

The chorionic gonadotropin administered to T.P. was obtained from Parke, Davis as Antuitrin S. J.R. received chorionic gonadotropin from Organon as Pregnyl and from Squibb as Follutein. ${ }^{3}$ J.R. also received $10 \mathrm{mg}$

\footnotetext{
${ }^{3} \mathrm{We}$ appreciate the generous gift of this material.
}

of Premarin (Ayerst) and $200 \mathrm{mg}$ progesterone (Pfizer) daily for a period of 10 days.

E. Oxygen dissociation curves. Oxygen dissociation curves were determined on aliquots of blood equilibrated in a separatory funnel as indicated above, collected under oil, and introduced into the Van Slyke apparatus (17), after hemoglobin and methemoglobin determinations had been carried out.

F. Serial osmotic hemolysis. Nine days after the intravenous administration of $10 \mu \mathrm{c}$ of $\mathrm{Fe}^{59}$-citrate, heparinized blood was drawn from Subject B.W. in order to carry out serial osmotic hemolysis studies. Ten $\mathrm{ml}$ of blood was centrifuged at $375 \mathrm{G}$ for 10 minutes. The plasma was discarded and ice-cold 0.9 per cent $\mathrm{NaCl}$ was added to give a total volume of $30 \mathrm{ml}$. The suspension was centrifuged at $2^{\circ} \mathrm{C}$ at $170 \mathrm{G}$ for 15 minutes and the supernatant discarded. At this temperature (and in the absence of glucose) no significant reduction of methemoglobin takes place. Buffered saline, prepared by the method of Dacie (18), equivalent to 0.65 per cent sodium chloride, was added to a total volume of $30 \mathrm{ml}$ and the resuspended red cells were incubated at $0^{\circ} \mathrm{C}$ for $10 \mathrm{~min}$ utes. The suspension was then centrifuged at $2^{\circ} \mathrm{C}$ for 15 minutes at $170 \mathrm{G}$. The supernatant was removed for hemoglobin, methemoglobin, and radioactivity determinations. Buffered saline, equivalent to 0.60 per cent sodium chloride, was then added and the procedure repeated. Subsequently, buffered saline, equivalent to 0.55 , $0.50,0.45,0.40,0.35,0.30,0.250 .20$, and 0.15 per cent was added. In each case, the hemolysate representing the cells hemolyzed by the salt strength used, but not by the previous salt strengths, was collected and assayed for hemoglobin, methemoglobin and radioactivity. The relatively few unhemolyzed cells remaining in the supernatant (because of the slow centrifuge speed used to avoid damage to cells) were hemolyzed by the addition of saponin. Serial osmotic lysis was carried out on the blood of T.P. using a higher centrifuge speed $(680 \mathrm{G})$ to remove all suspended erythrocytes. Radioactivity determinations were carried out on $7.00-\mathrm{ml}$ aliquots in a Nuclear-Chicago model DS 3 scintillator detector, model 1810 spectrometer, and model $161 \mathrm{~A}$ scaling unit.

G. Erythrocyte survival studies. $\mathrm{Cr}^{51}$ survival studies were carried out by adding sodium chromate (Rachromate, Abbott Laboratories) in 100 to $200 \mu \mathrm{c}$ quantities to approximately $30 \mathrm{ml}$ of blood. The plasma was removed after centrifugation and the cells were washed once in isotonic saline. Radioactivity determinations were carried out with the same equipment used for counting the $\mathrm{Fe}^{59}$. The blood volume was assumed to remain constant during the red cell survival studies and, therefore, no corrections for changes in hematocrit were made.

\section{RESULTS}

\section{A. In vitro studies}

1. Sickling-oxygen tension curves. Figures 1 and 2 demonstrate the effect of various concentra- 
tions of methemoglobin induced in vivo by the administration of sodium nitrite (Figure 1 ) or PAPP (Figure 2) on the distorting effects of low oxygen tensions on sickle cells. It is noted that there is well marked inhibition of red cell distortion. The criteria used for assessing distortion of red cells do not materially effect the relative position of the curve.

2. Oxygen dissociation curve of red cells containing methemoglobin. The percentage saturation with oxygen of red cells of Subject T.P. before and after methemoglobinemia was induced by PAPP is depicted in Figure 3. The presence of less than 25 per cent methemoglobin in red cells

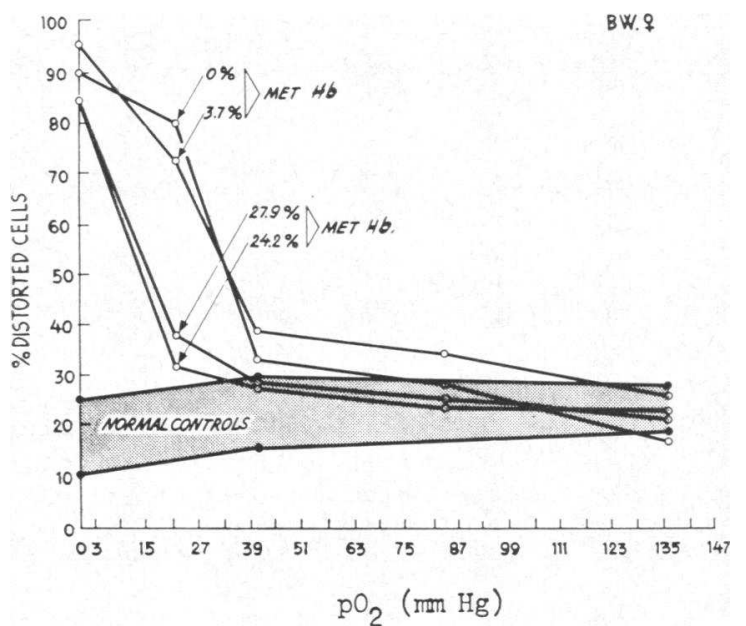

Fig. 1. EFFect of METHEMOgLobinemia induCED $N$ VIVO BY SODIUM NITRITE ADMINISTRATION ON THE SICKLING-OXYGEN TENSION CURVE OF ERYTHROCYTES. At low oxygen tensions there is less distortion of cells containing 24.2 and $27.9 \%$ methemoglobin than in those containing zero or $3.7 \%$ methemoglobin.

apparently exerts little effect on the dissociation of oxygen from oxyhemoglobin. Darling and Roughton (19), using normal red blood cells, have previously demonstrated that at low levels of methemoglobin the shift in the oxygen dissociation curve is slight. At the relatively low levels of methemoglobin used in our studies the shift in the oxygen dissociation curve might well have been too small to be detected in the limited number of measurements which we have made, if it occurred at all. Furthermore, in our calculations, the amount of hemoglobin available for dissociation has been estimated by subtracting the amount of methemoglobin present from the total hemoglobin

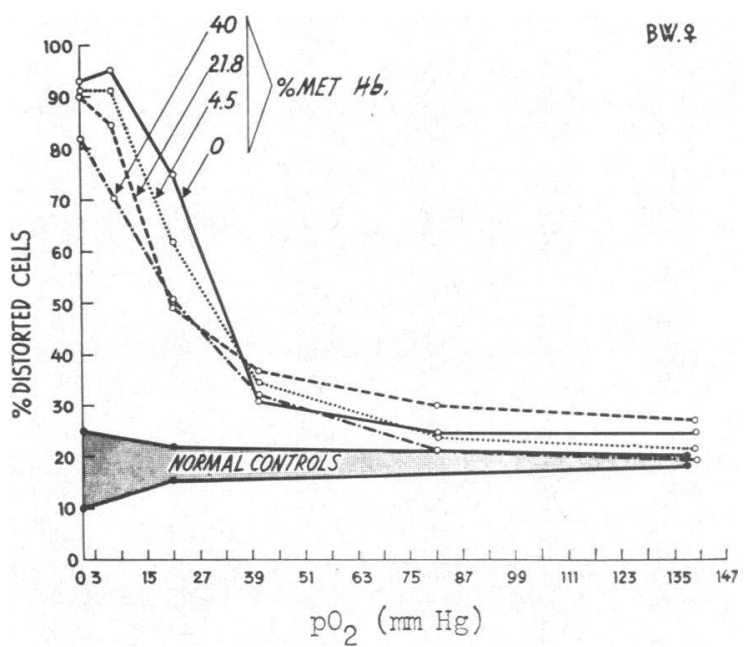

Fig. 2. EFFECT OF METHEMOGLOBINEMIA INDUCED $I . \mathrm{V}$ VIVO BY PAPP ON THE SICKLING-OXYGEN TENSION CURVE OF ERYTHROCYTES. At low oxygen tensions there is successively less distortion of cells as the amount of methemoglobin in the cells increases.

as determined by the cyanmethemoglobin method. If any additional pigments (hemoglobin degradation products) contributing to optical density but not capable of carrying oxygen, such as sulfhemoglobin, were present, these would give a falsely high estimation of the amount of hemoglobin pres-

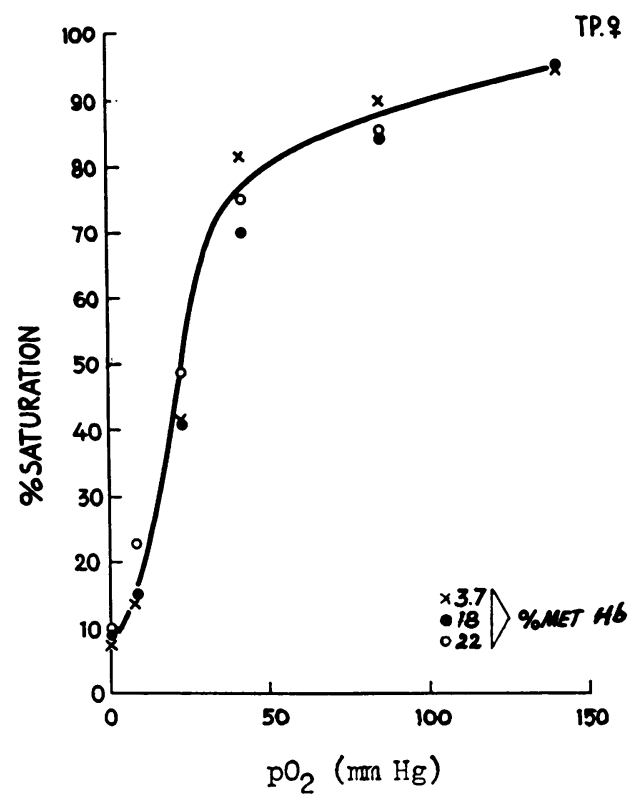

Fig. 3. Oxygen dissociation clrve of Sickle cells AT HIGH AND NEAR NORMAL METHEMOGLOBIN LEVELS. Methemoglobinemia was induced in vivo by the administration of PAPP. No significant change in the dissociation curve could be demonstrated. 


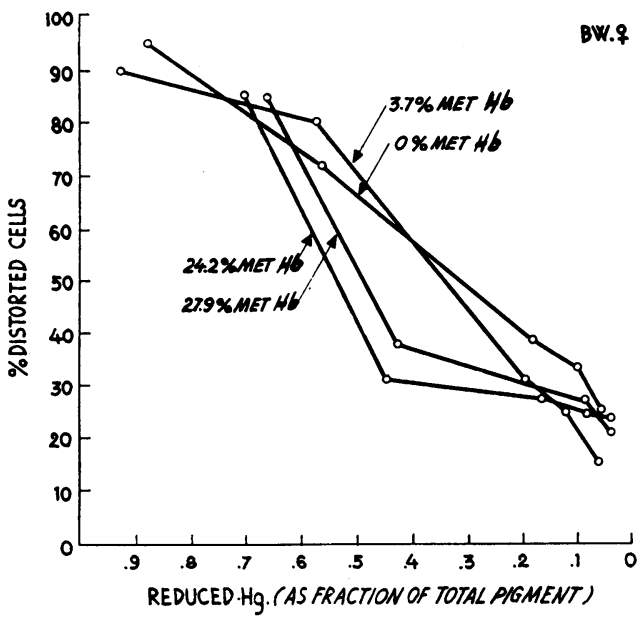

Fig. 4. EFFect of METheMoglobinemia indUCEd IN VIVO BY SODIUM NITRITE ADMINISTRATION ON THE SICKLING-REDUCED HEMOGLOBIN CURVE OF ERYTHROCYTES, AS DERIVED FROM FIgURES 1 AND 3 . The fraction of the total pigment in the form of reduced hemoglobin has been computed and appears as the abscissa. When expressed in this way, the percentage of cells distorted seems relatively independent of the percentage of methemoglobin in the red cells.

ent. In this way, the calculated oxygen dissociation curve would tend to be displaced to the right. This might obscure any slight leftward shift caused by the presence of methemoglobin. In agreement with the data of others (20-22), the oxygen dissociation curve of sickle cells appears

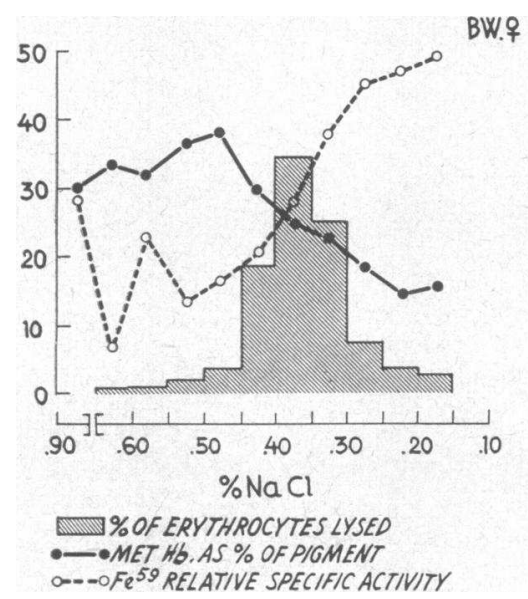

Fig. 5. Relationship between Cell age and metheMOGLOBIN CONTENT OF THE ERYTHROCYTES AS STUDIED BY FRACTIONAL OSMOTIC LYSIS. The cells most susceptible to lysis (presumably the older red cells) contain the greatest amount of methemoglobin. to be somewhat to the right of that usually presented for normal red blood cells.

3. Reduced hemoglobin-red cell distortion curves. Although, as shown in Figure 3, the presence of methemoglobin exerts relatively little effect on the dissociation of oxygen from oxyhemoglobin, the amount of the hemoglobin in each red cell participating in the hemoglobin-oxyhemoglobin equilibration is diminished when some of it has been converted to methemoglobin. To determine whether the presence of methemoglobin itself exerts an effect on the sickling process, or whether it exerts its action chiefly by removing hemoglobin from the $\mathrm{Hb} \rightleftarrows \mathrm{HbO}_{2}$ equilibrium, the curves correlating red cell distortion and oxygen tension have been

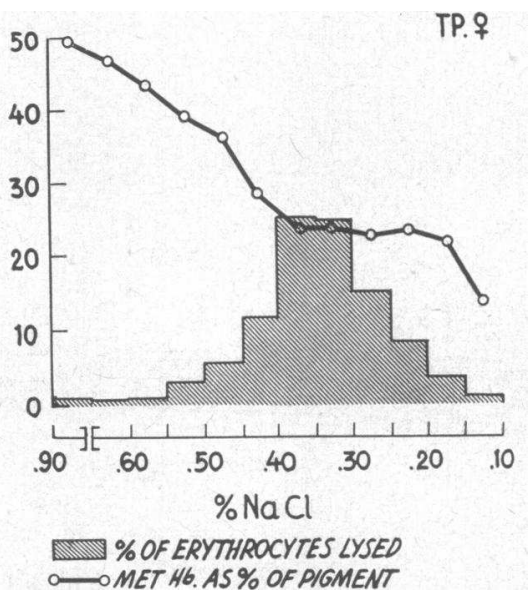

Fig. 6. Relationship Between cell age and MetheMOGLOBIN CONTENT OF THE ERYTHROCYTES AS STUDIED BY FRACTIONAL OSMOTIC LYSIS. The cells most susceptible to lysis (presumably the older red cells) contain the greatest amount of methemoglobin.

replotted to compare the proportion of the cells distorted with the concentration of reduced sickle hemoglobin in each cell. The reduced sickle hemoglobin concentration in the cell has been estimated by multiplying the percentage of reduced hemoglobin, as read from the oxygen dissociation curve (Figure 3 ), by the fraction of hemoglobin not converted to methemoglobin and, therefore, available for dissociation. The curves obtained show that the percentage of cells distorted is closely related to the reduced sickle hemoglobin concentration and is not greatly influenced by the presence of methemoglobin. Representative curves obtained by replotting data from Figure 1 are presented in Figure 4. 
$B$. The effect of cell age on methemoglobin levels

Ten $\mu \mathrm{c}$ of $\mathrm{Fe}^{59}$-citrate was given intravenously to Subject B.W. Maximal blood levels were achieved after 7 days. Nine days after the administration of $\mathrm{Fe}^{59}$, the patient was given $200 \mathrm{mg}$ of PAPP. One and one-half hours later, the blood methemoglobin level was approximately 40 per cent. Blood was drawn and the red cells were fractionated by differential osmotic hemolysis. The supernatant solutions were analyzed for amount of hemoglobin and the percentage of hemoglobin which was methemoglobin. These data are presented in Figure 5. In agreement with the data of Marks and Johnson (23) and of Levy,

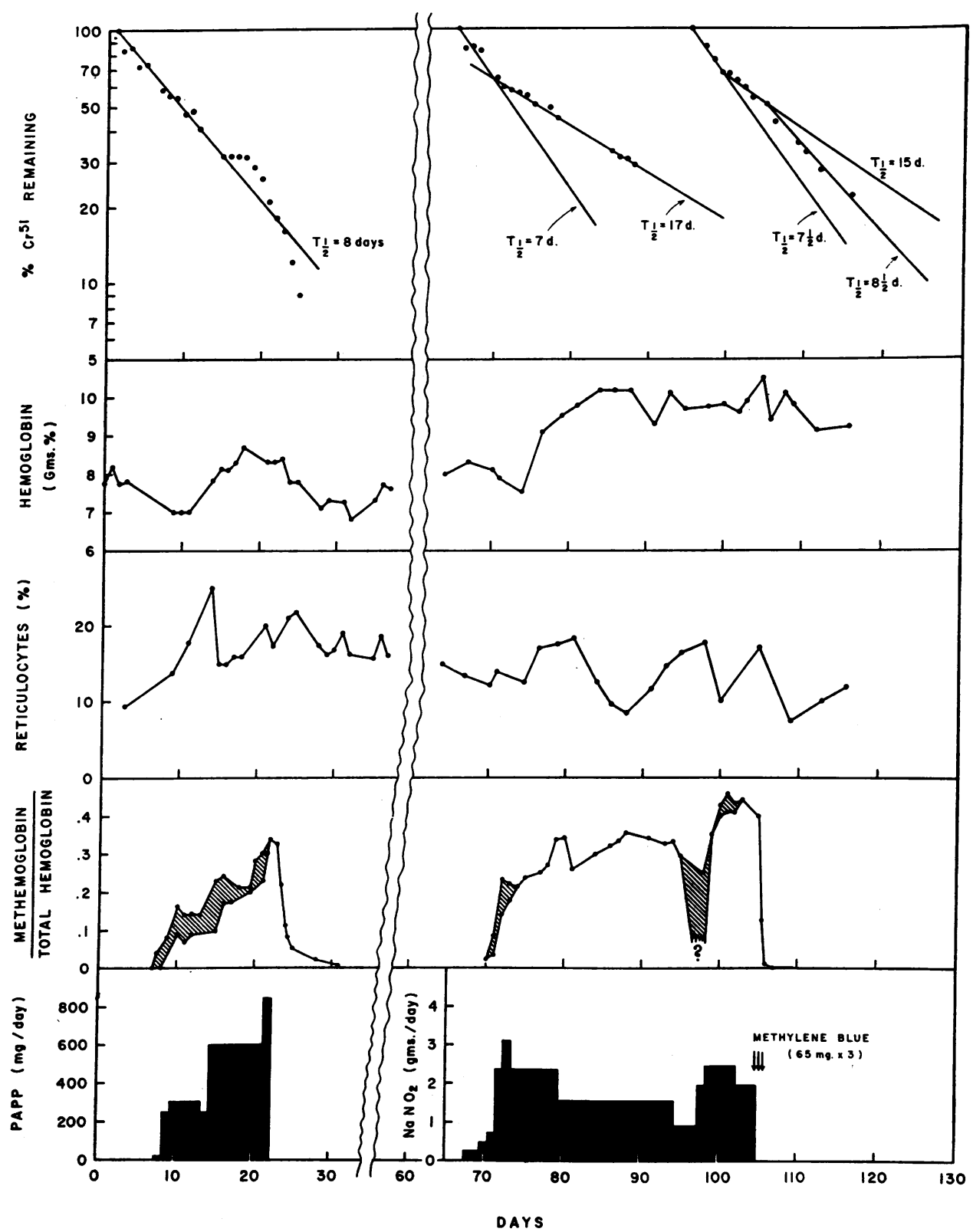

Fig. 7. Effect of PAPP and sodium Nitrite administration to L.A. on the metheMOGLOBIN CONTENT OF THE BLOOD, RETICULOCYTE COUNT, HEMOGLOBIN CONCENTRATION OF THE BLOOD AND $\mathrm{CR}^{51}$ RED CELL SURvival. The shaded areas in the methemoglobin panel of Figures 7-11 represent the range during the day when estimated from multiple daily determinations. 
Walter and Sass (24) on normal erythrocytes, the younger members of the sickle cell population, those labeled with $\mathrm{Fe}^{59}$, are most resistant to osmotic lysis. The slightly elevated $\mathrm{Fe}^{59}$ levels of the 0.65 and 0.55 per cent fractions may be due to the unusual fragility of a portion of the young cells, as was found in normal blood by Levy and co-workers (24), or to incomplete sedimentation of some reticulocytes at the relatively slow centrifuge speeds used. The younger red cell fractions contain the least methemoglobin. Very little radioiron was found in the $0.60,0.50$ and 0.45 per cent fractions and the maximal methemoglobin levels were encountered in these fractions. To determine whether the larger amounts of methemoglobin in the most easily lysed fractions were really a function of increased susceptibility of methemoglobin-containing cells rather than of cell age, differential osmotic hemolysis was repeated on the following day, after the methemoglobin concentration had returned to zero. There was no change in the susceptibility of the erythrocytes to osmotic lysis, indicating that the presence of methemoglobin does not increase the susceptibility of red cells to osmotic lysis. Two weeks later, the patient was again given $200 \mathrm{mg}$ PAPP. This time the $\mathrm{Fe}^{59_{-}}$ containing cells had aged somewhat and more radioactivity was found in the least resistant fractions. The pattern of methemoglobin formation was the same. Differential osmotic hemolysis studies were also carried out on the red cells of another patient, T.P., who had received PAPP for several weeks. A higher centrifuge speed was used to clear all remaining cells from the supernatant (see Methods). The relationship of the percentage of hemoglobin in the form of methemoglobin in various fractions as determined by this experiment is presented in Figure 6.

\section{Clinical observations}

1. Subject L.A. (Figure 7). The red cells of Subject L.A. were labeled with $\mathrm{Cr}^{51}$ and their survival followed for a baseline period of 7 days. PAPP was then administered at 4-hour intervals in gradually increasing doses, as shown in Figure 7. The percentage of methemoglobin increased concurrently. When the methemoglobin level reached approximately 20 per cent of the total pigment there was a striking increase in the survival of the red blood cells as estimated by the $\mathrm{Cr}^{51}$ method. This lasted for only a few days. In spite of continued drug administration and a rising level of methe- moglobin to a maximum of approximately 33 per cent of the total pigment, red cell destruction soon became accelerated and exceeded the baseline rate. This suggested that PAPP, an aromatic amine, was in itself hemolytic. Concurrently with the methemoglobinemia and lengthening of red cell survival, there was a modest reticulocytosis and a rise in the total hemoglobin level of the blood.

The patient's erythrocytes were rechromated approximately 1 month after the conclusion of the first study and methemoglobinemia was induced again, this time by administering gradually increasing doses of sodium nitrite. No toxic side effects from sodium nitrite were encountered, but the methemoglobin level rose to between 20 and 30 per cent of the total pigment. The baseline $\mathrm{Cr}^{51}$ half-time was 7 days, closely comparable with the 8-day $\mathrm{T}_{1}$ obtained on the patient in the previous study. During the period of methemoglobinemia, the $\mathrm{Cr}^{51}$ survival was lengthened to a $T_{\frac{1}{2}}$ of 17 days. There was no distinct change in the reticulocyte count and the total hemoglobin level of the blood rose. While still receiving sodium nitrite, the patient's erythrocytes were rechromated. Unfortunately, at this time the nighttime doses of nitrite were omitted for several days. It is not known to what level the methemoglobin concentration of the blood fell during this time. The $\mathrm{Cr}^{51} \mathrm{~T}_{\frac{1}{2}}$ was 7.5 days. After reinstitution of sodium nitrite therapy in full doses, the $T_{\frac{1}{2}}$ was lengthened to 15 days. Then nitrite administration was discontinued and three $65-\mathrm{mg}$ doses of methylene blue were administered orally, quickly lowering the methemoglobin level. Red cell destruction became somewhat accelerated with a $T_{1}$ of 8.5 days, closely comparable to the baseline levels of 8 and 7 days which were observed in the two previous $\mathrm{Cr}^{51}$ studies.

The patient had no acute symptoms at any time during the study and no change was noted in her general clinical status, serial electrocardiograms, urinalysis, or in her capacity to concentrate urine after water deprivation.

Comment. The administration of PAPP appeared to result in prolongation of red blood cell survival as estimated by the $\mathrm{Cr}^{51}$ method, but subsequently there was accelerated red cell destruction. The administration of sodium nitrite was associated with a more sustained prolongation of red cell survival. The possibility has been considered that the apparent prolongation of red cell survival in the second study was an artifact, produced by a heterogeneous red cell population comprised of short-lived and long-lived cells. This seems unlikely, since in the early portion of the first study there was no indication that there was a two-component population. However, a further attempt was made to rule out this possibility and to determine whether prolongation of red celllife span induced by sodium nitrite occurred in all 


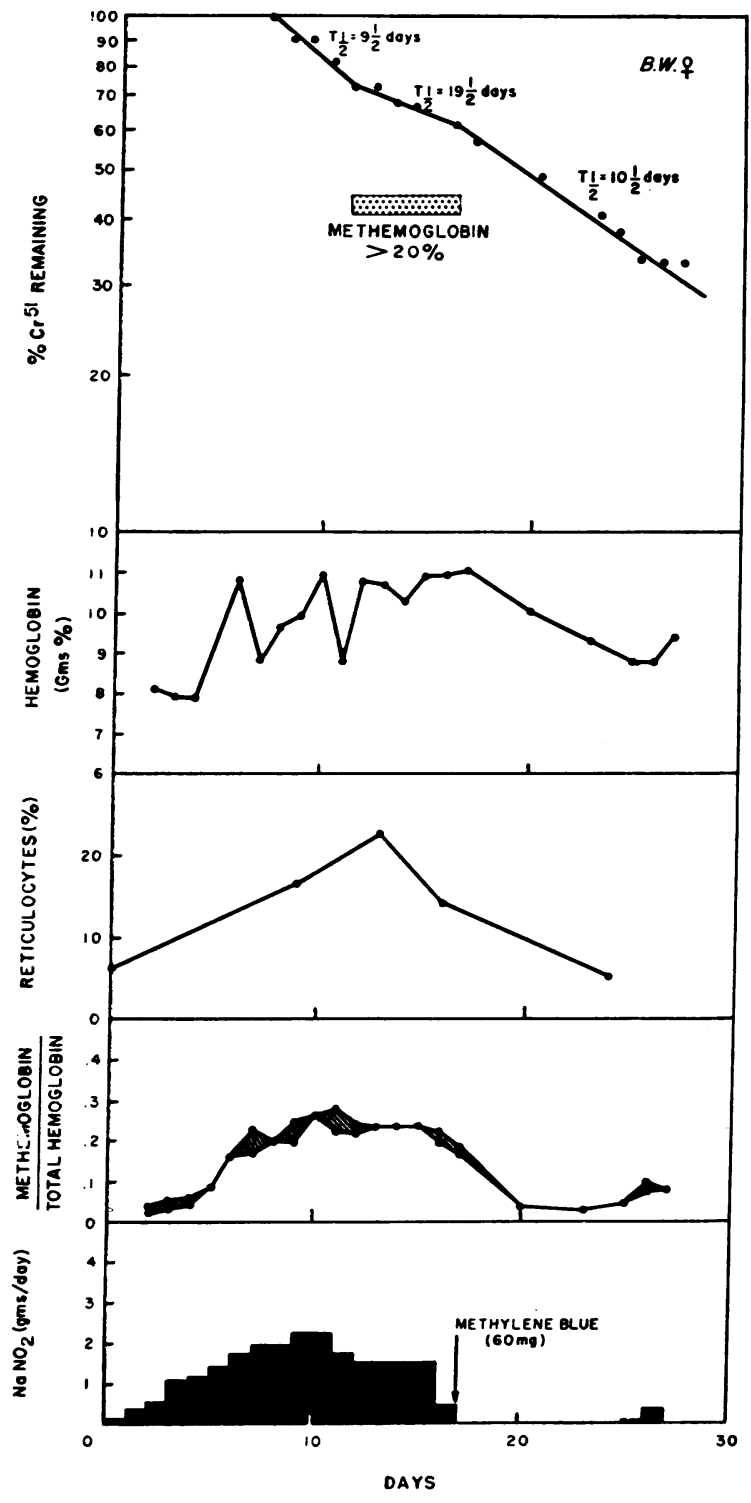

Fig. 8. EFFECT OF SODIUM NITRITE ADMINISTRATION To B.W.

members of the red cell population or only in the older cells (which contain a greater proportion of methemoglobin). Interpretation of this experiment is hampered by failure of the patient to receive nighttime doses of sodium nitrite. However, the third $\mathrm{Cr}^{51}$ study clearly demonstrates that the changes in the first two studies were not due merely to a mixed red cell population consisting of a long-lived and a short-lived component. It also shows that prolongation of red cell life span can be achieved, even in relatively young cells, when methemoglobinemia is induced by sodium nitrite administration.

It is impossible to determine whether the rise in the hemoglobin level which was observed was chiefly due to "driving" of the marrow as a result of the decreased oxyhemoglobin levels or to the decreased destruction of erythrocytes. Probably both mechanisms play a role, but the latter is emphasized in a later study carried out on T.P. (see below).

2. Subject B.W. (Figure 8). B.W. was given gradually increased doses of sodium nitrite. Her red cells were chromated when her methemoglobin level was already between 15 and 20 per cent of the total pigment (Figure 8). Before the level of methemoglobinemia was consistently greater than 20 per cent, the $T_{1}$ was 9.5 days, as computed by the method of least squares (25). A $\mathrm{T}_{\text {; }}$ of 19.5 days was found when a curve was fitted to the points obtained after methemoglobin levels above 20 per cent of the total pigment were consistently achieved. Upon withdrawal of sodium nitrite and administration of methylene blue to hasten the conversion of methemoglobin to hemoglobin, red cell survival was for the next 8 days shortened to a $T_{1}$ of 10.5 days, closely comparable to the original $T_{1}$ of 9.5 days.

No unusual clinical symptoms were observed. However, approximately 1 week after the methemoglobin level had returned to zero, the patient developed a mild, painful crisis. This seemed to provide an opportunity to study the effect of methemoglobin production on this complication. Small doses of sodium nitrite were administered. There was an apparent lengthening of red cell survival, although since the observations made were scanty, their significance remains somewhat doubtful. The painful symptoms subsided in approximately 24 hours. Relief of pain was not impressive. Several months later, we were presented with another opportunity to observe the patient during a painful crisis. The results of administration of a single dose of PAPP were approximately the same. Rapid induction of methemoglobinemia of 29 to 36 per cent for 1 hour did not seem to affect the pain, which subsided after about 48 hours. No attempt to induce prolonged methemoglobinemia was made.

Comment. This study confirms that prolongation of survival of even relatively young erythrocytes can be achieved when sodium nitrite is administered. Efforts to influence painful crises yielded disappointing results, although such results are difficult to evaluate because of the marked variability in the natural history of painful crises.

3. Subject T.P. (Figure 9). The red cells of T.P. were labeled with $\mathrm{Cr}^{51}$ and baseline survival studied for several days. Methemoglobinemia was induced with PAPP on two occasions-first for 6 , then for 7 days. 


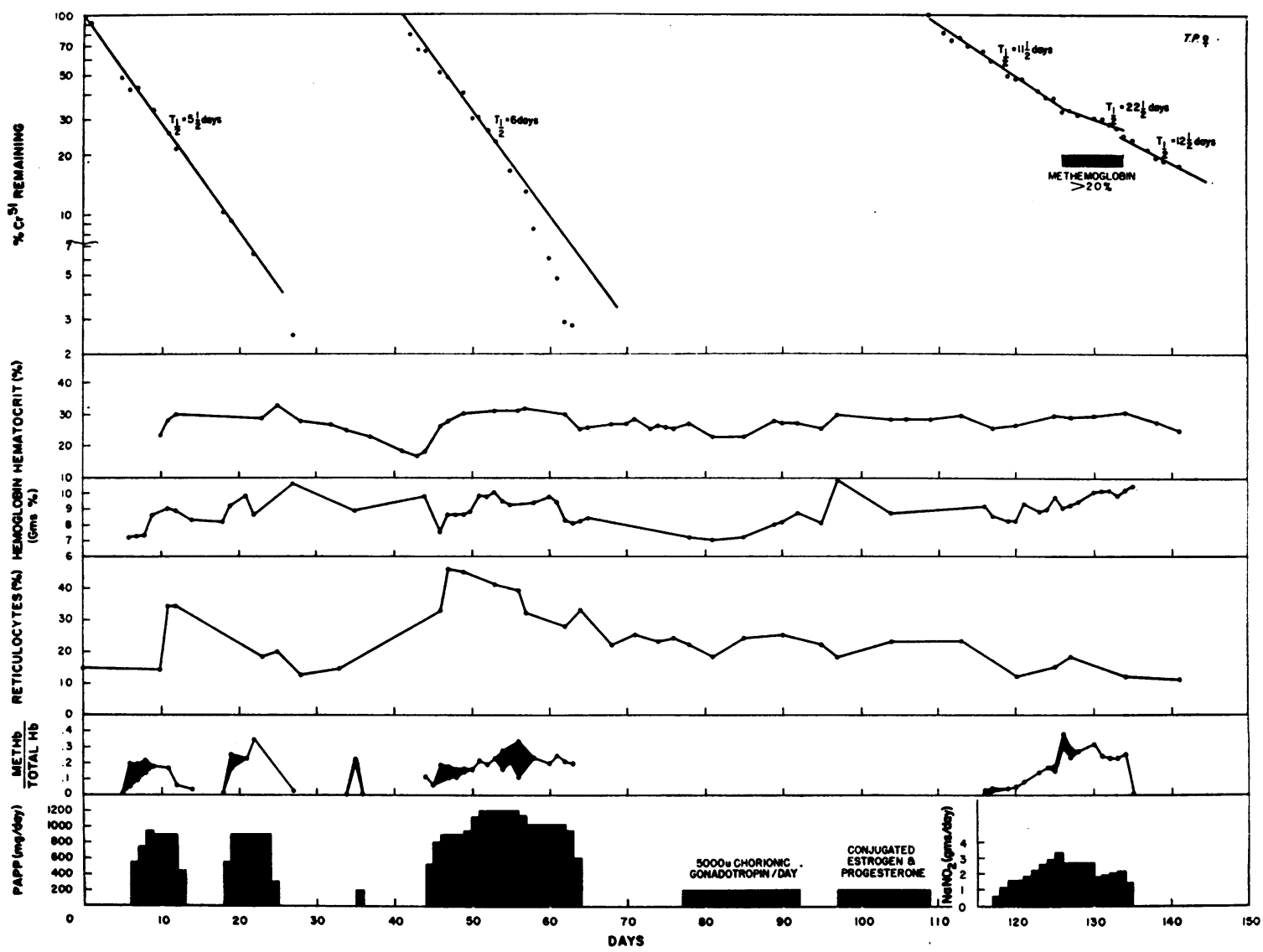

Fig. 9. EfFEct of PAPP and sodium Nitrite administration to T.P.

No significant alteration of $\mathrm{Cr}^{51}$ survival was observed. The reticulocyte count and hematocrit rose slightly, and hemoglobin showed a questionable increase. Two weeks following the second course of PAPP administration, the patient developed chest pain, fever, and a pulmonary infiltrate of the right base. She was treated with anticoagulants for the next 2.5 weeks, and her symptoms and signs quickly disappeared. The patient's red cells were again labeled with $\mathrm{Cr}^{51}$ and a more prolonged course of treatment with PAPP lasting 19 days was carried out. There was only questionable, transient prolongation of $\mathrm{Cr}^{51}$ survival lasting for a few days and then accelerated destruction, as had been observed in the study carried out on L.A. However, there was a well marked rise in the hematocrit, not accompanied by a rise in the hemoglobin. Thus, the patient's mean corpuscular hemoglobin concentration fell. This apparently anomalous finding was easily explained when her red cells were examined for Heinz bodies. Most of the cells contained these particles, probably consisting of denatured protein (26). The patient was next given a short course of injections with chorionic gonadotropin in an effort to influence fetal hemoglobin synthesis. The results were equivocal : a rapid rise of alkali-resistant hemoglobin was followed by a return to near baseline level while hor- mone was still being administered. The administration of conjugated equine estrogens and progesterone resulted in no change in alkali-resistant hemoglobin levels.

A third $\mathrm{Cr}^{51}$ survival study was carried out to determine whether methemoglobinemia induced by nitrite would prolong red cell survival in this patient as it had in Subjects L.A. and B.W. The baseline $\mathrm{Cr}^{51}$ survival time was longer than that found in the two earlier studies, with a $T_{\frac{1}{2}}$ of 11.5 days, as computed by the method of least squares (25). This prolongation may be explained by the fact that the patient had just experienced accelerated red cell destruction as a result of PAPP administration. Drug-induced hemolytic anemia affects chiefly the older members of the red cell population (27); thus, prolonged survival may be expected following drug-induced hemolysis. When sodium nitrite was administered to the patient the $\mathrm{Cr}^{51}$ survival time remained unchanged, with a computed $T_{1}$ of 11.5 days, until the methemoglobin level consistently exceeded 20 per cent of the total pigment. The slope of the survival curve then changed to give a computed $T_{\frac{1}{2}}$ of 22.5 days. After sodium nitrite administration was discontinued the slope of the survival curve returned to 13 days, comparable with that of the period before sodium nitrite administration. During the course of the study the patient's leg 
ulcers healed rapidly. There was no change in her capacity to concentrate urine after water deprivation and no change in her general clinical condition.

Comment. In this patient, the hemolytic effect of protracted PAPP administration was confirmed. It was again demonstrated that sodium nitrite could prolong red cell survival at methemoglobin levels at which no significant prolongation was achieved with PAPP. The healing of the leg ulcers could probably be attributed as easily to the extended period of hospitalization as to any beneficial effects from the administration of methemoglobin-forming agents.

4. Subject J.G. (Figure 10). The red cells of J.G. were labeled with $\mathrm{Cr}^{51}$ and she was given gradually increased doses of sodium nitrite every 4 hours. After 9 days, the patient was receiving $390 \mathrm{mg}$ sodium nitrite every 4 hours and complained of headache. However, methemoglobin levels were only about 11 per cent. Therefore, the dosage of sodium nitrite was increased by one-third to $520 \mathrm{mg}$ for one dose. When this dose failed to produce any further symptoms and the methemoglobin level was still well below 20 per cent, an additional dose of $260 \mathrm{mg}$ sodium nitrite was given after 2 hours. Two hours later there were no symptoms, although the blood pressure was 100/0. Another 520-mg dose of sodium nitrite was administered. About 1.5 hours later, the patient complained of substernal pain which lasted for about 10 minutes and disappeared when oxygen was given. The methemoglobin level at the time of pain was only 22 per cent of the total pigment. An electrocardiogram taken shortly after the pain subsided showed no change from the previous tracing, except for a more rapid rate and the appearance of supraventricular extrasystoles. An EKG taken 3 days later was entirely normal. The dosage of sodium nitrite was decreased to $390 \mathrm{mg}$ every 4 hours. There were no further symptoms and the dose was increased to $455 \mathrm{mg}$, at which time the patient again developed an episode of chest pain, which subsided in a few minutes after administration of oxygen and codeine. The methemoglobin level at this time was only 19 per cent. Further administration of sodium nitrite to J.G. was abandoned. In the course of the study there were no changes in serial urinalysis, serum bilirubin determinations, or capacity to concentrate urine after water deprivation.

Taken as a whole the $\mathrm{Cr}^{51}$ survival curve does not deviate significantly from the baseline curve. The minor fluctuations which occurred do not coincide either with changes in nitrite dosage or with the methemoglobin level and are not readily explained.

Comment. This subject had the most severe degree of anemia of any of the patients studied, and consequently her red cells have the youngest average age. Probably because the methemo- globin-reducing systems of young cells are more active than those of older red cells (28), it was impossible to achieve adequate levels of methemoglobinemia in this patient without encountering alarming toxic side effects from sodium nitrite.

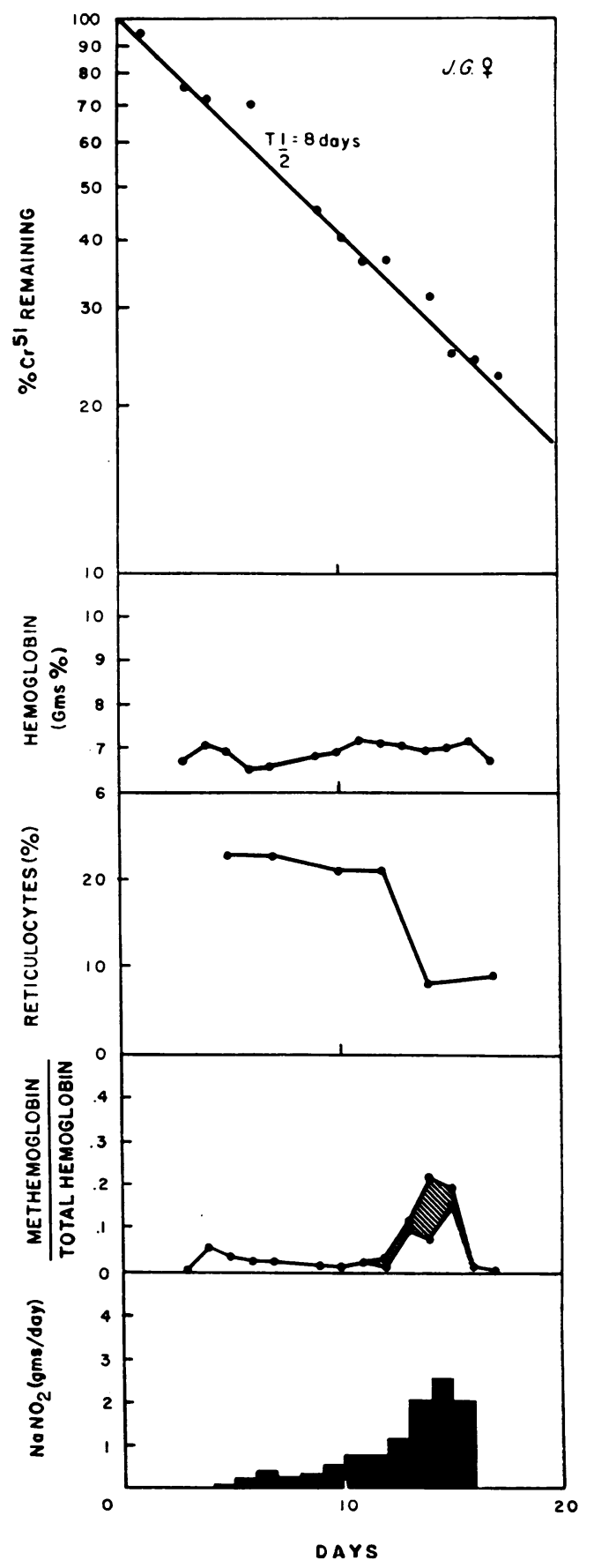

Fig. 10. EfFect of Sodium Nitrite adimistration To J.G. 


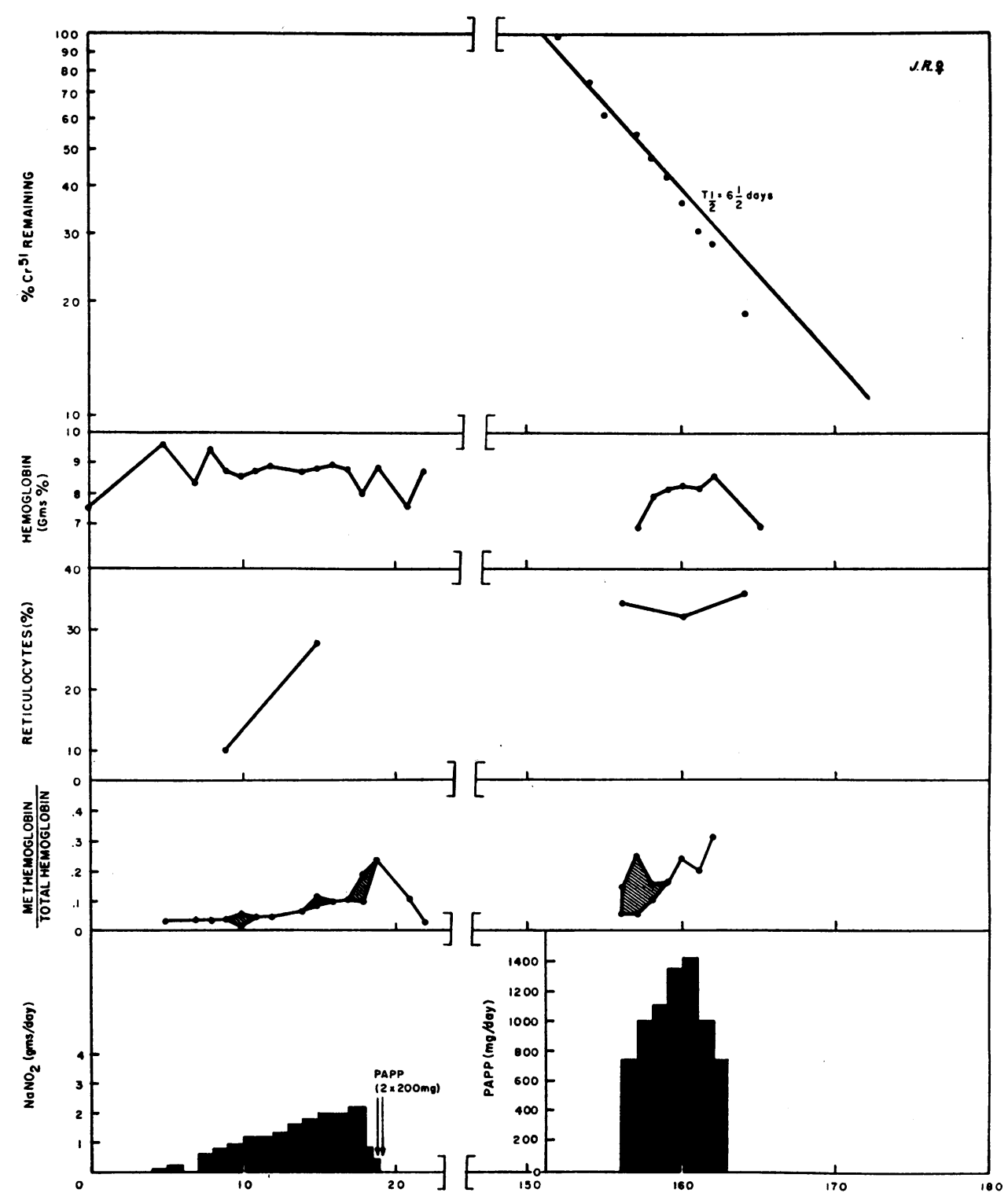

Fig. 11. Effect of PAPP and sodium nitrite administration to J.R.

5. Subject J.R. (Figure 11). J.R. was given gradually increased doses of sodium nitrite which resulted in a gradual rise in her methemoglobin level. When the dosage had reached $325 \mathrm{mg}$ every 4 hours, the patient experienced epigastric burning but the methemoglobin level remained at approximately 10 per cent of the total pigment. It was therefore deemed wise to discontinue sodium nitrite administration. A $\mathrm{Cr}^{\text {o1 }}$ survival curve was, unfortunately, unsatisfactory because the red cells had been washed with a sodium chloride solution containing 0.9 per cent benzoic acid as a preservative. Subsequent investigations demonstrated that benzoic acid at this concentration damages red cells, increasing their osmotic fragility and causing, upon injection, their almost immediate removal from the circulation. A second study was initiated in which PAPP was administered. Methemoglobinemia of between 20 and 30 per cent was achieved without any untoward symptoms. There was no prolongation of $\mathrm{Cr}^{51}$ survival, and indeed, there was accelerated destruction of red cells within a few days' time after PAPP administration had been initiated. There was no change in the patient's general clinical status, serial electrocardiograms, urinalysis, bilirubin level or capacity to concentrate urine on water deprivation. Two days after discharge from the hospital, the patient developed an episode of nausea, vomiting and 
diarrhea which subsided spontaneously within about 24 hours, and which was considered to be unrelated to either her sickle cell disease or the experimental therapy. Several months after these studies were conducted, this patient was also given a course of chorionic gonadotropin, $10,000 \mathrm{U}$ daily. A slight rise in alkali-resistant hemoglobin was observed, but a higher level had been observed previously while the patient was receiving no hormone therapy.

Comment. Some degree of accelerated red cell destruction in a patient receiving PAPP was again demonstrated.

\section{DISCUSSION}

It is usually assumed that the clinical manifestations of sickle cell disease are due to the abnormal physicochemical properties of sickle hemoglobin, which result in the distortion of the red cells when the oxygen tension is reduced. It must be admitted, however, that although it is reasonable to assume that sickling of red cells is responsible for the clinical course of sickle cell disease (29), this assumption can by no means be considered proven. There are discrepancies between the number of sickled cells and the severity of the clinical disease, and it has been suggested that other disturbances of red cell function may be important clinically (4). Nonetheless, it might be possible to influence favorably the course of this disease by changing the composition of hemoglobin within the red cells in such a way that the extent of sickling would be diminished. An ideal solution to the problem of sickling of erythrocytes would be to induce synthesis of type A hemoglobin to take the place of synthesis of type $S$ hemoglobin. This is technically beyond our reach today, for the patient with sickle cell disease does not have the genetic potential for the synthesis of type $A$ hemoglobin and changing the genetic constitution of human tissues is not yet feasible.

A second, probably almost as satisfactory solution, might be to induce synthesis of large amounts of type $F$ hemoglobin in the red cells of patients with sickle cell disease in the place of hemoglobin S. Patients with sickle cell disease do have the potential for synthesis of the gamma chain of the hemoglobin molecule, and indeed normally produce increased amounts of fetal hemoglobin (30). Fetal hemoglobin interferes with the sickling process in infants (10) and in hereditary persistence of fetal hemoglobin (31). As yet, no method for increasing the synthesis of $F$ hemoglobin is known, although sensitivity in the ratio between hemoglobin $F$ and hemoglobin $A$ synthesized to oxygen tension has been demonstrated $(32,33)$. The alteration of this ratio is due, however, to the fact that while both hemoglobin $\mathrm{F}$ and hemoglobin A synthesis is inhibited by anoxia, the degree of inhibition is greater in the case of hemoglobin A. The observation (34) that cyanotic congenital heart disease does not appear to be associated with the appearance of hemoglobin $F$ suggests that anoxia is not an important regulatory factor. It has also been observed, by using alkali denaturation and immunologic technique $(35,36)$, that there is increase in fetal hemoglobin content of the mother's blood during the second trimester of normal pregnancy and during molar pregnancy. This has not been confirmed with sensitive measurements using the tryptophan fine-line spectrum after alkali denaturation (34). Nonetheless, the possibility that the hormonal environment might influence fetal hemoglobin synthesis appeared to us to warrant further investigation. A transient rise in alkali-resistant hemoglobin was observed in two patients following chorionic gonadotropin administration, but its significance is as yet uncertain. Further studies are obviously necessary. This problem is currently under investigation in our laboratory.

A third approach is to modify the hemoglobin within the red cell chemically without attempting to influence the type of hemoglobin which is synthesized by the red cell precursor. In this paper, the potential value of converting sickle hemoglobin to methemoglobin is examined. An ideal chemical modification of hemoglobin would be such that: 1) the modified compound would continue to carry oxygen and carbon dioxide normally, 2) its modification would be induced by the administration of nontoxic agents, 3) infrequent drug administration by the oral route would suffice to produce the desired change in hemoglobin in a reliable fashion with a minimum of laboratory control, 4) sickling would be effectively inhibited even at relatively low oxygen tensions. It is obvious that drug-induced methemoglobinemia falls seriously short in several respects. Frequent administration of drugs with certain toxic side effects with appropriate laboratory controls is required to maintain an adequate level of methemoglobin in the blood. 
Methemoglobin does not carry oxygen. However, it does, as we have confirmed in this study, effectively inhibit the sickling process. Substantial inhibitions of sickling can be achieved with a compromise of only about 20 per cent of the oxygen-carrying capacity of the blood. In agreement with the conclusions drawn from studies in experimental animals by Jalavisto and associates (37-39), and in human red cells by Jung (40) and Waller, Schlegel, Müller and Löhr (41), the methemoglobin concentration of the older red cells was greater than that of the younger members of the red cell population. Thus, very marked inhibition of sickling of some of the cells may have been achieved. The current studies shed some light on the mechanisms of inhibition of sickling by methemoglobin. It would appear that methemoglobin exerts its chief effect by removing pigment from the equilibrium between reduced hemoglobin and oxyhemoglobin rather than by interfering with the sickling process in a manner analagous to the interference produced by fetal hemoglobin (10). In effect, it renders the red cell hypochromic with respect to hemoglobin, thus reducing the absolute amount of reduced sickle hemoglobin present at a given oxygen tension and diminishing the tendency of the red cell to be deformed.

Regardless of the mechanism of the effect of methemoglobin in inhibiting sickling, the cautious trial of methemoglobin-forming agents in the treatment of sickle cell disease seemed to us to be justified. Many treatments of sickle cell disease have been advocated in the past; none is considered satisfactory (5). To our knowledge, the studies we have reported here represent the first experimental therapy which has been shown to prolong red cell survival. The effect of inducing methemoglobinemia with PAPP and sodium nitrite has been investigated in five patients with sickle cell disease. When methemoglobin levels above 20 per cent were produced with sodium nitrite there was a consistent prolongation of red blood cell survival. At lower methemoglobin levels, no such prolongation of red cell survival was observed. PAPP failed to produce any sustained significant prolongation of red cell survival, even at methemoglobin levels considerably higher than those achieved with sodium nitrite. This is in all likelihood due to the fact that PAPP, an aromatic amine, is itself hemolytic. The possibility has been considered that sodium nitrite produces prolongation of red cell survival by a mechanism independent of the methemoglobinemia which it induces. Sodium nitrite is known to have marked effects on the vascular system, and it is conceivable that these may be responsible, in part, for its effect in prolonging red blood cell survival. However, the patient who failed to develop significant degrees of methemoglobinemia, even with large amounts of sodium nitrite (J.G.), failed to experience sustained prolongation of red blood cell survival.

Methemoglobinemia was well tolerated by all of the patients. This was true even when relatively large amounts of methemoglobin were formed in a brief period of time. This is consistent with the point of view that the clinical manifestations of sickle cell disease are not due primarily to the anemia. Neither could any clinical benefit be ascribed to the induction of methemoglobinemia, nor was the renal concentrating defect influenced. The latter finding is not surpris- ing in view of the fact that the renal defect of patients with sickle cell disease is only reversible in early childhood (42).

It has been known for some time that tolerance to the side effects of nitrites develops upon continued exposure. Thus, it has been pointed out that munitions factory workers may suffer from nitrite-induced headaches during the first few days of employment. They are subsequently asymptomatic unless they leave work for several days. Upon return to work they often develop headaches again. Workers have learned to avoid these symptoms by continuing to expose themselves to nitrite by placing a small quantity of nitroglycerin in their hatbands so that it will be absorbed through the skin (43). There is conflicting evidence as to whether tolerance can be induced to sodium nitrite $(44,45)$, although there is general agreement about other nitrites. Nonetheless, we were able to administer large doses of nitrite to most of our patients by using gradually increased doses without encountering side effects. This was not true in all cases, however. One patient (J.G.) developed alarming symptoms when the sodium nitrite dosage was increased rapidly, and symptoms recurred at the same level of nitrite even when the dosage was increased slowly. Another 
patient (J.R.) developed symptoms which were sufficiently annoying to make it seem advisable to discontinue therapy. Aside from these toxic side effects of nitrite administration, it is obviously impractical to administer any drug to patients every 4 hours, day and night, over a long period of time. If methemoglobinemia were to have any practical value in the long-term therapy of sickle cell disease, it would have to be induced by a preparation which could be administered at much less frequent intervals. On the other hand, it is conceivable that short-term methemoglobinemia might be of value in the treatment of crises. We have hesitated to give sodium nitrite in the treatment of crises, however, since the tolerance to the vascular effects is variable. Administration of enough, nitrite to result in formation of methemoglobin levels sufficient to affect the sickling phenomenon might result in serious side effects. PAPP, on the other hand, might have some promise in the therapy of crises, since high levels of methemoglobin can be induced within less than an hour by the administration of this compound. Our limited experience with the use of this material in the treatment of painful crises has been disappointing. Since the course of crises is variable, a more extensive controlled trial would be necessary to determine whether the administration of this compound is of value in crises.

\section{SUMMARY}

1. The induction of methemoglobinemia in vivo by the administration of para-aminopropriophenone (PAPP) or of sodium nitrite produced a shift to the left in the sickling-oxygen tension curve of the red cells of patients with sickle cell disease.

2. Conversion of 20 per cent of the sickle cell hemoglobin to methemoglobin produced such an effect, but did not materially influence the oxygen dissociation curve of the intact red blood cells.

3. Most or all of the effect of methemoglobin in inhibiting sickling could be explained on the basis of removal of pigment from the oxyhemoglobinreduced hemoglobin equilibrium, resulting in a lower concentration of reduced sickle hemoglobin at a given oxygen tension.

4. More methemoglobin was present in the older members of the red cell population than in young red cells of patients with sickle cell disease after administration of PAPP.

5. When sodium nitrite was administered to patients with sickle cell disease and the methemoglobin concentration of the blood reached levels greater than 20 per cent of the total pigment, there was an increase in the survival of red blood cells, as estimated by the $\mathrm{Cr}^{51}$ method. There was also a tendency for the hemoglobin content of the blood to rise.

6. When methemoglobinemia was induced in patients with sickle cell disease by the administration of PAPP, there was in at least one case transient prolongation of red blood cell survival as estimated by the $\mathrm{Cr}^{51}$ method. In all cases in which PAPP was administered for more than a few days, there was eventually accelerated destruction of red cells as estimated by this method. Administration of PAPP was sometimes associated with an increase of the hematocrit not accompanied by increase in hemoglobin concentration of the blood. This was attributed to denaturation of some of the hemoglobin within the red cells to Heinz bodies.

7. In none of the patients was there any subtantial change in clinical status during drug administration, although alarming side effects were noted in one patient at high dosages of sodium nitrite and another patient noted troublesome side effects from sodium nitrite administration. Preliminary attempts to treat painful crises of patients with sickle cell disease by the administration of sodium nitrite yielded unimpressive results.

\section{REFERENCES}

1. Greenberg, M. S., and Kass, E. H. Alkali in the treatment of painful crises in patients with sickle cell anemia (abstract). J. clin. Invest. 1956, 35, 707.

2. Hilkovitz, G. Sickle-cell disease: New method of treatment (preliminary report). Brit. med. J. 1957, 2, 266.

3. Henderson, A. B., Crockett, E. J., and Wright, C. H. Effect of carbonic anhydrase inhibitors on the course of sickle-cell disease. A. M. A. Arch. intern. Med. 1959, 104, 68.

4. Jensen, W. N., Rucknagel, D. L., and Taylor, W. J. In vivo study of the sickle cell phenomenon. J. Lab. clin. Med. 1960, 56, 854.

5. Dacie, J. V. Haemolytic Anaemias, Congenital and Acquired. Part I. Congenital Anaemias, 2nd ed. London, Churchill, 1960.

6. Harris, J. W. The role of physical and chemical factors in the sickling phenomenon in Progress in 
Hematology, L. M. Tocantins, Ed. New York, Grune \& Stratton, 1959, vol. 2, pp. 47-109.

7. Itano, H. A. Sickle Cell Anemia (Ph.D. thesis). California Institute of Technology, 1950.

8. Greenberg, M. S., Kass, E. H., and Castle, W. B. Studies on the destruction of red blood cells. XII. Factors influencing the role of $\mathrm{S}$ hemoglobin in the pathologic physiology of sickle cell anemia and related disorders. J. clin. Invest. 1957, 36, 833.

9. Singer, K., and Singer, L. Studies on abnormal hemoglobins. VIII. The gelling phenomenon of sickle cell hemoglobin: Its biologic and diagnostic significance. Blood 1953, 8, 1008.

10. Shields, G. S., Lightman, H. C., Messite, J., and Watson, R. J. Studies in sickle cell disease. I. Quantitative aspects of sickling in the newborn period. Pediatrics 1958, 22, 309.

11. Beutler, E. The effect of in vivo modification of sickle hemoglobin on a patient with sickle-cell disease (abstract). Clin. Res. 1960, 8, 101.

12. Paterson, J. C. S. Personal communication.

13. Evelyn, K. A., and Malloy, H. T. Microdetermination of oxyhemoglobin, methemoglobin, and sulfhemoglobin in a single sample of blood. J. biol. Chem. 1938, 126, 655.

14. Beutler, E., Dern, R. J., and Alving, A. S. The hemolytic effect of primaquine. VI. An in vitro test for sensitivity of erythrocytes to primaquine. J. Lab. clin. Med. 1955, 45, 40.

15. Betke, K., Marti, H. R., and Schlicht, I. Estimation of small percentages of foetal haemoglobin. Nature (Lond.) 1959, 184, 1877.

16. Beutler, E., and Mikus, B. The effect of sodium nitrite and PAPP administration on blood methemoglobin levels and red blood cell survival. Blood. In press.

17. Peters, J. P., and Van Slyke, D. D. Quantitative Clinical Chemistry. Vol. II. Methods. Baltimore, Williams \& Wilkins, 1932.

18. Dacie, J. V. Haematological techniques useful in the investigation of haemolytic anaemias in The Haemolytic Anaemias, Congenital and Acquired. London, Churchill, 1954, pp. 476-477.

19. Darling, R. C., and Roughton, F. J. W. The effect of methemoglobin on the equilibrium between oxygen and hemoglobin. Amer. J. Physiol. 1942, 137, 56.

20. Fowler, N. O., Smith, O., and Greenfield, J. C. Arterial blood oxygenation in sickle cell anemia. Amer. J. med. Sci. 1957, 234, 449.

21. Becklake, M. R., Griffiths, S. B., McGregor, M., Goldman, H. I., and Schreve, J. P. Oxygen dissociation curves in sickle cell anemia and in subjects with the sickle cell trait. J. clin. Invest. 1955 , 34, 751.

22. Rodman, T., Close, H. P., Cathcart, R., and Purcell, M. K. The oxyhemoglobin dissociation curve in the common hemoglobinopathies. Amer. J. Med. $1959,27,558$.
23. Marks, P. A., and Johnson, A. B. Relationship between the age of human erythrocytes and their osmotic resistance: A basis for separating young and old erythrocytes. J. clin. Invest. 1958, 37, 1542.

24. Levy, L. M., Walter, H., and Sass, M. D. Enzymes and radioactivity in erythrocytes of different ages. Nature (Lond.) 1959, 184, 643.

25. Moroney, J. J. Facts from Figures. Penguin Books, Harmondsworth, Middlesex, 1951, chap. 16.

26. Webster, S. H. Heinz body phenomenon in erythrocytes. A review. Blood 1949, 4, 479.

27. Beutler, E., Dern, R. J., and Alving, A. S. The hemolytic effect of primaquine. IV. The relationship of cell age to hemolysis. J. Lab. clin. Med. 1954, 44, 439.

28. Löhr, G. W., Waller, H. D., Karges, O., Schlegel, B., and Müller, A. A. Zur Biochemie der Alterung menschlicher Erythrocyten. Klin. Wschr. 1958, 36,1008 .

29. Editorial. Sickle cells. Lancet 1959, 2, 331.

30. Singer, K., Chernoff, A. I., and Singer, L. Studies on abnormal hemoglobins. I. Their demonstration in sickle cell anemia and other hematologic disorders by means of alkali denaturation. Blood 1951, 6, 413.

31. Herman, E. C., Jr., and Conley, C. L. Hereditary persistence of fetal hemoglobin: A family study. Amer. J. Med. 1960, 29, 9.

32. Thomas, E. D., Lochte, H. L., Jr., Greenough, W. B., III, and Wales, M. In vitro synthesis of foetal and adult haemoglobin by foetal haematopoietic tissues. Nature (Lond.) 1960, 185, 396.

33. Allen, D. W., and Jandl, J. H. Factors influencing relative rates of synthesis of adult and fetal hemoglobin in vitro. J. clin. Invest. 1960, 39, 1107.

34. Beaven, G. H., Ellis, M. J., and White, J. C. Studies on human foetal haemoglobin. II. Foetal haemoglobin levels in healthy children and adults and in certain haematological disorders. Brit. J. Haemat. 1960, 6, 201.

35. Rucknagel, D. L., and Chernoff, A. I. Immunologic studies of hemoglobins. III. Fetal hemoglobin changes in the circulation of pregnant women. Blood 1955, 10, 1092.

36. Bromberg, Y. M., Salzberger, M., and Abrahamov, A. Alkali resistant type of hemoglobin in women with molar pregnancy. Blood 1957, 12, 1122.

37. Jalavisto, E. Bleeding anemia and methemoglobin reduction in dog erythrocytes. Acta physiol. scand. 1959, 46, 252.

38. Jalavisto, E., Pitkanen, A., Selonen, A., and Solantera, $\mathrm{L}$. The rate of methemoglobin reduction in red cells of moderately bled rabbits. Acta physiol. scand. 1959, 46, 257.

39. Jalavisto, E., and Solantera, L. Methemoglobin reduction rate of nitrite treated red cells as a function of cell age. Acta physiol. scand. 1959, 46, 273. 
40. Jung, F. Alter, hämolytische Resistenz und $\mathrm{Me}-$ thämoglobingehalt der Erythrocyten. Dtsch. Arch. klin. Med. 1949, 195, 454.

41. Waller, H. D., Schlegel, B., Müller, A. A., and Löhr, G. W. Der Hämiglobingehalt in alternden Erythrocyten. Klin. Wschr. 1959, 37, 898.

42. Keitel, H. G., Thompson, D., and Itano, H. A. Hyposthenuria in sickle cell anemia: A reversible renal defect. J. clin. Invest. 1956, 35, 998.

43. Ebright, G. E. The effects of nitroglycerin on those engaged in its manufacture. J. Amer. med. Ass. 1914, 62, 201.
44. Myers, H. B., and Austin, V. T. Nitrite toleration. J. Pharmacol. exp. Ther. 1929, 36, 227.

45. Crandall, L. A., Jr., Leake, C. D., Loevenhart, A. S., and Muehlberger, C. W. Acquired tolerance to and cross tolerance between the nitrous and nitric acid esters and sodium nitrite in man. J. Pharmacol. exp. Ther. 1931, 41, 103.

46. Beutler, E. Modification of the sickling process and of in vivo survival of sickle cells by the administration of methemoglobin-forming agents (abstract). Blood 1961, 17, 376. 